\title{
Temperature-driven proliferation of Tetracapsuloides bryosalmonae in bryozoan hosts portends salmonid declines
}

\author{
S. Tops, W. Lockwood, B. Okamura* \\ School of Biological Sciences, Philip Lyle Research Building, University of Reading, Whiteknights, PO Box 228, \\ Reading RG6 6BX, UK
}

\begin{abstract}
Proliferative kidney disease (PKD) is an emerging disease of salmonid fishes. It is provoked by temperature and caused by infective spores of the myxozoan parasite Tetracapsuloides bryosalmonae, which develops in freshwater bryozoans. We investigated the link between PKD and temperature by determining whether temperature influences the proliferation of T. bryosalmonae in the bryozoan host Fredericella sultana. Herein we show that increased temperatures drive the proliferation of $T$. bryosalmonae in bryozoans by provoking, accelerating and prolonging the production of infective spores from cryptic stages. Based on these results we predict that PKD outbreaks will increase further in magnitude and severity in wild and farmed salmonids as a result of climate-driven enhanced proliferation in invertebrate hosts, and urge for early implementation of management strategies to reduce future salmonid declines.
\end{abstract}

KEY WORDS: Temperature $\cdot$ Climate change $\cdot$ Salmonids $\cdot$ Proliferative kidney disease $\cdot$ Myxozoa Freshwater bryozoans · Covert infections

\section{INTRODUCTION}

Disease outbreaks in natural and agricultural systems are increasing in both severity and frequency (Daszak et al. 2000, Subasinghe et al. 2001). Such emerging diseases in marine ecosystems have been linked to human-mediated influences through (e.g.) introduction of disease agents, overfishing, domestic stock disease reservoirs, pollution and climate change (Lafferty et al. 2004). An apparent example in freshwater systems is proliferative kidney disease (PKD). PKD is caused by a myxozoan parasite and results in significant economic loss to the rainbow trout fish farming industry and salmonid hatcheries (Hedrick et al. 1993). All salmonids are believed to be susceptible and the effects on wild stock are generally poorly known (Hedrick et al. 1993, Feist et al. 2002). However, recent research has indicated that PKD is widespread in Swiss midland rivers and can cause over $25 \%$ mortality in resident brown trout populations (Wahli et al. 2002, Borsuk et al. 2006).
The source of PKD was obscure until freshwater bryozoans (benthic, colonial invertebrates) were identified recently as hosts of the causative agent (Anderson et al. 1999), which was described as Tetracapsuloides bryosalmonae (Canning et al. 1999, 2002) and placed in the new class Malacosporea (phylum Myxozoa) (Canning et al. 2002). The parasite produces overt infections when spore-filled sacs develop in the body cavity of bryozoans (Canning et al. 1999, Kent et al. 2001, Canning \& Okamura 2004). Mature spores released into the water column are infective for fishes (Feist et al. 2001). The parasite can also persist as covert infections, with cryptic stages detected by PCR and in situ hybridisation (Tops \& Okamura 2003, Tops 2004). These cryptic stages exploit the highly clonal nature of bryozoan hosts and achieve long-term, endemic infections in bryozoan populations, presumably by multiplying in concert with growing and fragmenting bryozoan hosts (Tops et al. 2004). Infection of fishes entails attachment of spores by eversion of a coiled filament and invasion by amoeboid cells 
through the epithelium. The parasite then multiplies in fishes as extrasporogonic stages, primarily in the kidney and spleen, and fish hosts mount a massive cellmediated immune response (Hedrick et al. 1993). The role of fishes in the life cycle of $T$. bryosalmonae is unresolved. Most evidence suggests that they are accidental and dead-end hosts (see Henderson \& Okamura 2004 and references therein), and transmission from fishes back to bryozoans has so far not been achieved (Tops et al. 2004). It is becoming increasingly clear that the maintenance of endemic infections in clonally replicating bryozoans provides a constant source of infection for fishes (Tops 2004, Tops et al. 2004, this study).

PKD outbreaks are highly seasonal, generally occurring after waters have reached $15^{\circ} \mathrm{C}$ (Hedrick et al. 1993). Although fishes can become infected by Tetracapsuloides bryosalmonae at low temperatures $\left(<10^{\circ} \mathrm{C}\right)$, PKD will not develop (Gay et al. 2001). In addition to provoking outbreaks, increased temperatures appear to promote disease severity (Naich et al. 2003). Clines in PKD with regard to temperature are apparent. Brown trout suffer from the disease in lower altitudinal regions of Switzerland (Wahli et al. 2002) and, although PKD has been recorded in northern Europe (Hedrick et al. 1993), it is of greatest concern in salmonid aquaculture further south (e.g. southern England, France and Italy). Given the strong influence of temperature on PKD, the disease is likely to become an increasing problem in wild and farmed fish populations as a consequence of climate change. Indeed, this may already be happening in Switzerland, where significant increases in the maximum annual water temperature have been documented in stretches of Swiss rivers where PKD-impacted brown trout populations have been in decline (Wahli et al. 2002, Borsuk et al. 2006).

The relationship between PKD and temperature may be explained by several factors. Elevated temperatures may promote bryozoan growth and thus increase host resources for exploitation by parasites. In addition, increased temperatures may induce proliferation of Tetracapsuloides bryosalmonae in bryozoan hosts, resulting in the release of parasitic stages infective to fishes. Finally, as the fish immune system is activated by increases in temperature (Le Morvan et al. 1998), higher temperatures could promote disease progression. Since the source of PKD is critical to its development, we investigated whether temperature influences the proliferation of $T$. bryosalmonae in bryozoan hosts. Herein we show that increased temperatures provoke, accelerate and prolong the proliferation of infective stages. These results provide a clear warning, predicting that PKD outbreaks will increase in both magnitude and severity in wild and farmed salmonids due to climate-driven enhanced proliferation of parasites in invertebrate hosts as global temperatures rise. Disease management strategies implemented now, such as coordinated efforts to reduce thermal discharges, might avoid or reduce crisis management at a later date in some systems.

\section{MATERIALS AND METHODS}

General methods. Fredericella sultana Blumenbach, 1779 is one of the main bryozoan hosts of Tetracapsuloides bryosalmonae (Okamura \& Wood 2002). F. sultana grows as tubular, branching colonies that are formed by budding of interconnected zooids. Colonies form intertwined and dense stands as a result of spreading growth. F. sultana colonies were collected each month from August to December 2004 from a population growing on willow roots in the River Cerne, Dorset, UK, known to harbour T. bryosalmonae infections (Longshaw et al. 1999, Tops 2004). On each sampling date, the bryozoans were collected haphazardly by gently detaching branching colonies from the root systems of 3 willow trees. The willow trees occur along a $17 \mathrm{~m}$ stretch of the river directly upstream from a fish farm that suffers annual PKD outbreaks. Collections were always made at a similar time of day (10:00 to 11:00 h) and river water temperatures were measured. The bryozoans were returned to the laboratory in containers with river water, in a coolbox with freezer blocks.

Background levels of overt infections at the time of collection were assessed by shredding 150 haphazardly chosen 'colonies' per willow root system. Colonies were defined as individual branches that were detached from other associated branches. Such branches typically comprised from 8 to 13 zooids. Since colonies growing in the field are opaque, the presence of Tetracapsuloides bryosalmonae sacs can only be detected by shredding branches to release sacs.

Experimental colonies were obtained by inducing individual branches to attach (via the sticky tips of branches; Tops et al. 2004) to Petri dishes containing river water. Establishment of colonies on the dishes allowed subsequent monitoring of parasite development with a dissection microscope. Because the complete life cycle of Tetracapsuloides bryosalmonae is unknown and we are as yet unable to effect laboratory transmission to bryozoans, studying the development of infective stages necessarily relies on collecting large numbers of bryozoans from known infected populations in order to obtain sufficient material to discover parasite development (Tops 2004). We placed 20 branches in individual Petri dishes for $48 \mathrm{~h}$ to allow attachment at room temperature $\left(20^{\circ} \mathrm{C}\right)$ in anticipation that only a proportion of colonies would attach successfully. Petri dishes with established attached 
colonies were then placed in aquarium culture systems maintained at 10,14 and $20^{\circ} \mathrm{C}$ in constant temperature rooms under conditions of constant light. The 10 and $20^{\circ} \mathrm{C}$ culture systems consisted of an aerated mother tank (volume = 221 l) containing pondwater and goldfish and 4 identical side tanks (individual side tank volume = 16 l). Water recirculated between the mother and side tanks in which the bryozoans were placed. Colonies from the same collection were maintained in the same side tanks. Possible complications resulting from pseudoreplication are addressed in the 'Discussion'. The incorporation of fishes and seeding of the culture systems with pondwater promotes microbial growth and establishes appropriate conditions for suspension feeding bryozoans (Tops et al. 2004). Because of lack of space, the $14^{\circ} \mathrm{C}$ culture system consisted of a single 161 aquarium tank whose water was entirely replaced with fresh $14^{\circ} \mathrm{C}$ pondwater every 1 to $3 \mathrm{~d}$. A pilot study confirmed the suitability of this regime for bryozoan growth.

All experimental colonies were examined every 3 to $4 \mathrm{~d}$ with a dissection microscope for overt infection and to monitor colony growth. Non-destructive monitoring of overt infections is feasible in laboratory-cultured material, since Fredericella sultana cannot incorporate sediment in its outer walls, a process that obscures detection of infection in colonies growing in the field. During these observations we also confirmed that the colonies were not food-limited in any culture system. The digestive tract of well-fed colonies takes on the colour of ingested food and waste products appear in longitudinal bands, giving a striped appearance (Wood \& Okamura 2005). Colony growth was monitored by counting the number of zooids per colony for a period of $28 \mathrm{~d}$ and was standardised by determining per capita growth rates (number of new zooids at successive time intervals/number of zooids at previous time interval). Mean per capita growth rates per colony were then calculated based on their per capita growth rates until the end of the trial or when the colony died.

Expt 1: Does temperature promote overt infection? This experiment assessed whether temperatures differentially influence the development of overt infections by culturing colonies at 10,14 and $20^{\circ} \mathrm{C}$. Trials were conducted on colonies collected each month from August through December 2004, allowing us to determine whether the development of overt infections varied seasonally on the basis of data for summer (August trial), autumn (September and October trials) and winter (November and December trials). For each trial, 360 branches were placed into 18 Petri dishes for each temperature treatment (a total of 1080 colonies). Colonies which successfully attached were then observed for 4 wk (28 d), except in December when the last set of observations was on the 26th day. At the end of trials conducted on material collected in August, October and December, colonies that were larger than 1 zooid were washed and saved individually for PCR using Tetracapsuloides bryosalmonae-specific primers and appropriate controls (see Tops \& Okamura 2003) to identify colonies with covert infections during summer, autumn and winter periods. In assessing levels of covert infection, we excluded colonies that showed any sign of possible infection on the last day of trials (e.g. those which contained possible spores released from sacs or very early stages of sac development) since their infection status was ambiguous.

Expt 2. Does a temperature switch affect overt infection? This experiment was designed to assess more specifically whether a switch in temperature influences the development of overt infections and whether this is dependent on the duration of time before the temperature switch. Colonies were broken down into 2 groups: one group was maintained at $10^{\circ} \mathrm{C}$ for $3 \mathrm{wk}$ prior to transfer to $20^{\circ} \mathrm{C}$ for $3 \mathrm{wk}_{\text {; the second }}$ group was maintained at $10^{\circ} \mathrm{C}$ for 6 wk prior to transfer to $20^{\circ} \mathrm{C}$ for $3 \mathrm{wk}$. The experiments were conducted in summer (August) and autumn (October). We allowed 200 branches to attach to 10 Petri dishes for each of the 3 and 6 wk trials.

\section{RESULTS}

\section{Expt 1: Does temperature influence overt infection?}

Fig. 1a depicts the percentage (and frequencies) of colonies with and without overt infections for material collected in summer, autumn and winter and maintained at the 3 different temperatures. We excluded colonies that died during the course of the 4 wk culture period if overt infections were not observed, but included colonies in which overt infections developed but which subsequently died, since our interest was in whether temperature influenced sac proliferation. Loglinear analysis indicated that the proliferation of sacs was dependent on both temperature $\left(\chi^{2}=53.358\right.$, $\mathrm{df}=2, \mathrm{p}<0.001)$ and time $\left(\chi^{2}=56.542, \mathrm{df}=2, \mathrm{p}<0.001\right)$. The proportion of colonies with overt infections was always lower at $10^{\circ} \mathrm{C}$ than at 14 and $20^{\circ} \mathrm{C} \mathrm{(Fig.} \mathrm{1a),} \mathrm{and}$ the proportions were greatest in winter for all temperatures. Overt infections developed in a smaller proportion of colonies at $20^{\circ} \mathrm{C}$ in autumn than in summer and winter, but this was not the case for colonies at 14 and $10^{\circ} \mathrm{C}$ (reflecting the significant time $\times$ temperature interaction: $\chi^{2}=18.198, \mathrm{df}=4, \mathrm{p}=0.001$ ).

The percentage of colonies with covert infections was consistently lower for colonies maintained at $20^{\circ} \mathrm{C}$ than those maintained at 14 or $10^{\circ} \mathrm{C}$ and remained relatively constant over the 3 time periods (Fig. 1b). In 
contrast, the percentage of colonies harbouring cryptic stages increased from summer to winter for colonies maintained at 14 and $10^{\circ} \mathrm{C}$, and the increase was greater at the lower temperature (Fig. 1b). Log-linear
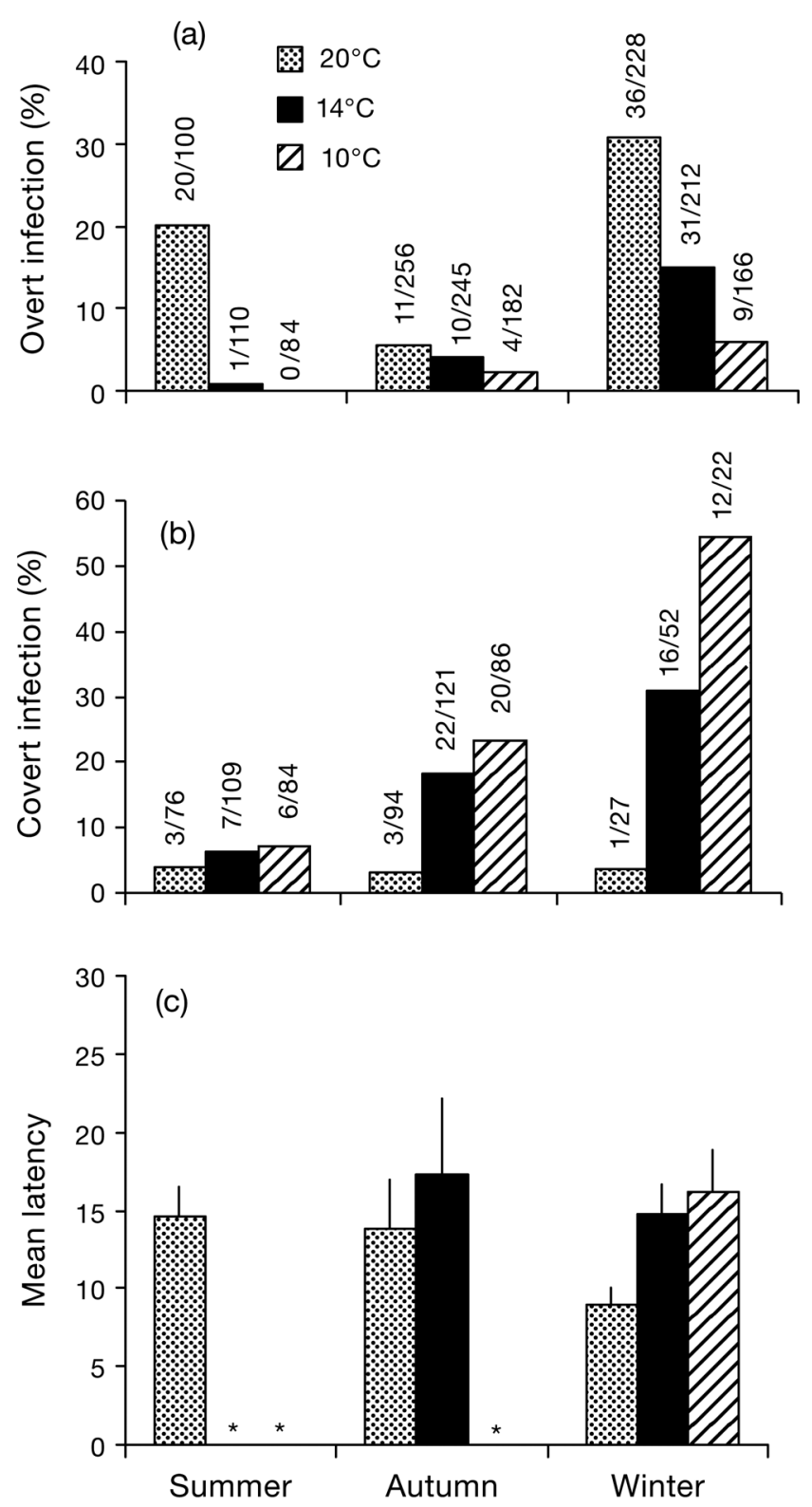

Fig. 1. Fredericella sultana infected with Tetracapsuloides bryosalmonae. Percentage of bryozoan colonies collected from the field in summer, autumn and winter that developed (a) overt and (b) covert (positive PCR) infections during laboratory culture for $4 \mathrm{wk}$ at different temperatures. Nos. above bars: total no. of colonies with infection/total no. of colonies examined (see 'Materials and methods' for further details). (c) Mean latency of infection in colonies at different seasons and temperatures; (*) no data for colonies at $14^{\circ} \mathrm{C}$ in summer and $10^{\circ} \mathrm{C}$ in summer and autumn, as $<5$ cases of overt infections developed during these trials, bars $=\mathrm{SE}$ analysis of the frequencies of colonies with (positive PCR) and without (negative PCR) covert infections during summer, autumn and winter trials at different temperatures indicated that covert infections were dependent on both temperature $\left(\chi^{2}=30.197, \mathrm{df}=2, \mathrm{p}<\right.$ $0.001)$ and time $\left(\chi^{2}=34.797, \mathrm{df}=2, \mathrm{p}<0.001\right)$. We are confident that false positive PCR results do not confound interpretation of covert infections (via contamination) for several reasons. Firstly, we obtained positive PCR results for trials in which no overt infections developed (e.g. summer trials at $10^{\circ} \mathrm{C}$ ) (see also similar results in Tops \& Okamura 2003). In addition, the soft, unprotected spores degrade in $<24 \mathrm{~h}$ (de Kinkelin et al. 2002), and we obtained positive results in other trials where all overt infections had disappeared at least $3 \mathrm{~d}$ before the end of the experiment (e.g. summer trial at $14^{\circ} \mathrm{C}$ ). Furthermore, we found differences in growth rates of colonies with (growth accelerated) and without covert infections (data to be reported in a separate publication). Finally, as spores of Tetracapsuloides bryosalmonae that develop in bryozoans do not appear to reinfect bryozoans (Tops et al. 2004) they would not be expected to attach to bryozoans.

Latency of infection (number of days before overt infections were observed) was influenced by both season and temperature, although low n-values precluded some analyses. Fig. 1c plots the mean values for cases when $>5$ colonies developed overt infections during the $4 \mathrm{wk}$ trials (note asterisks denote cases where insufficient data were available). The latency period was shortest in winter for colonies maintained in laboratory culture at $20^{\circ} \mathrm{C}$ (ANOVA: $F_{2,57}=13.825, \mathrm{p}<$ $0.0001)$. There was no significant difference in latency period for colonies maintained in laboratory culture at $14^{\circ} \mathrm{C}$ between autumn and winter (ANOVA: $F_{1,39}=$ $1.324, \mathrm{p}=0.257$ ). Latency increased with decreasing culture temperatures in winter (ANOVA: $F_{2,66}=$ $16.590, \mathrm{p}<0.0001)$. When the data were pooled over time, latency of infection was reduced with increasing temperature (ANOVA: $F_{2,112}=6.267, \mathrm{p}=0.0026$; mean latency for $20^{\circ} \mathrm{C}=11.73, \mathrm{SD}=4.80, \mathrm{n}=60$; mean latency for $14^{\circ} \mathrm{C}=15.19, \mathrm{SD}=5.96, \mathrm{n}=42$; mean latency for $10^{\circ} \mathrm{C}=15.62, \mathrm{SD}=6.09, \mathrm{n}=13$ ).

Duration of overt infection was assessed by considering the number of instances in which we observed overt infections on a single occasion vs. the number of instances when overt infections were observed over consecutive observations during the trial period (Table 1). Since some infections persisted to the end of the trial period, their potential duration is unknown. To ensure appropriate expected values, frequency analyses were performed on pooled data. Duration of infection depended on temperature when pooled over time $\left(\chi^{2}=\right.$ 96.401, $\mathrm{df}=2, \mathrm{p}<0.001)$. At $14^{\circ} \mathrm{C}$, an overall higher proportion of colonies $(53.7 \%)$ had overt infections dur- 
Table 1. Fredericella sultana infected with Tetracapsuloides bryosalmonae. Number of bryozoan colonies in which overt infection was observed on single vs. consecutive occasions at different temperatures during summer, autumn and winter trials in 2004

\begin{tabular}{|clrc|}
\hline \multirow{2}{*}{$T\left({ }^{\circ} \mathrm{C}\right)$} & \multicolumn{2}{c|}{ Observations } \\
\cline { 2 - 3 } & & Single & Consecutive \\
\hline 20 & Summer & 4 & 16 \\
& Autumn & 10 & 1 \\
& Winter & 25 & 10 \\
14 & Summer & 1 & 0 \\
& Autumn & 5 & 5 \\
& Winter & 14 & 17 \\
10 & Summer & 0 & 0 \\
& Autumn & 3 & 1 \\
& Winter & 6 & 3 \\
\hline
\end{tabular}

ing consecutive observations vs. at $10^{\circ} \mathrm{C}(30.8 \%)$ and $20^{\circ} \mathrm{C}(23.9 \%)$. There were sufficient data to assess the effect of season on duration of infection in the 20 and $14^{\circ} \mathrm{C}$ trials. At $20^{\circ} \mathrm{C}$, infection duration was dependent on season $\left(\chi^{2}=19.369, \mathrm{df}=2, \mathrm{p}<0.001\right)$ : a high proportion of overt infections occurred over consecutive time periods in summer $(80.0 \%)$, while in autumn and winter the majority of overt infections were observed on only a single occasion (90.9 and $71.4 \%$, respectively). At $14^{\circ} \mathrm{C}$, duration of infection was not dependent on season $\left(\chi^{2}=0.124, \mathrm{df}=1, \mathrm{p}>0.5\right)$ : in autumn and winter a similar proportion of colonies sustained overt infections during consecutive observations (50.0 and 54.8\%, respectively).

Table 2 provides the background levels of overt infections assessed at the time of collecting experimental colonies along with the temperature of the river at the time of sampling. There was a consistent pattern of notably higher prevalence of overt infections in laboratory trials conducted at higher temperatures relative to field prevalences and temperatures.

Table 2. Fredericella sultana infected with Tetracapsuloides bryosalmonae. Background levels of overt infection and associated river temperature each month. Level of overt infection, presented as the number of $F$. sultana colonies with overt infection/total number of colonies shredded (percentage). $11 \mathrm{Aug}=$ summer trials; $8 \mathrm{Sep}, 6$ Oct $=$ autumn trials; 3 Nov, $1 \mathrm{Dec}=$ winter trials (see 'Materials and methods' for details)

\begin{tabular}{|lcc|}
\hline Date $(2004)$ & Infection level & $T\left({ }^{\circ} \mathrm{C}\right)$ \\
\hline 11 Aug & $11 / 450(2.4 \%)$ & 14 \\
8 Sep & $5 / 450(1.1 \%)$ & 14 \\
6 Oct & $7 / 450(1.6 \%)$ & 11 \\
3 Nov & $66 / 450(14.7 \%)$ & 11 \\
1 Dec & $31 / 450(6.9 \%)$ & 6 \\
\hline
\end{tabular}

\section{Expt 2: Does a temperature switch affect overt infection?}

In all cases overt infections developed in a greater number of cases after colonies were placed at the higher temperature in both summer and autumn (Table 3). Binomial tests of the difference in frequencies of colonies developing overt infections before and after transfer to higher temperature were significant in 3 of the 4 cases (Table 3 ).

A comparison of sac development in colonies maintained at $10^{\circ} \mathrm{C}$ for $6 \mathrm{wk}$ vs. colonies maintained at $10^{\circ} \mathrm{C}$ for $3 \mathrm{wk}$ and then switched to $20^{\circ} \mathrm{C}$ for $3 \mathrm{wk}$ provided evidence that the development of overt infections was not a function of time. In both summer $\left(\chi^{2}=15.99\right.$, $\mathrm{df}=$ $1, \mathrm{p}<0.001)$ and autumn $\left(\chi^{2}=8.02\right.$, df $\left.=1, \mathrm{p}<0.005\right)$, development of overt infection was dependent on trial, with sacs proliferating in a much greater proportion of colonies in trials that included exposure to $20^{\circ} \mathrm{C}$ (Table 4). Finally, overt infections developed during subsequent further culturing at $20^{\circ} \mathrm{C}$ in $11(20.8 \%)$ and $16(40.0 \%)$ colonies which had been exposed to $10^{\circ} \mathrm{C}$ for $6 \mathrm{wk}$ (Trials B and D, respectively).

\section{DISCUSSION}

\section{Increasing temperature promotes parasite proliferation}

Fig. 2 illustrates the generalised thermal sensitivity profiles of the parasite inferred from the overall patterns of our results. The figure comprises a summary of our results and a reference for the following discussion, but the relative positions and exact shapes of response trajectories remain unclear and are likely to show some variation with season. Furthermore, non-linear re-

Table 3. Fredericella sultana infected with Tetracapsuloides bryosalmonae. Number of bryozoan colonies (cols) in which overt infection developed before and after culture at $20^{\circ} \mathrm{C}$ (total number of colonies that survived the trial period), and $\mathrm{p}$ values for 2-tailed binomial tests based on $H_{0}$ that sacs proliferated in an equal number of colonies before and after the temperature switch (Siegel \& Castellan 1988). Trials A and $\mathrm{C}$ entailed $3 \mathrm{wk}$ at $10^{\circ} \mathrm{C}$ followed by 3 wk at $20^{\circ} \mathrm{C}$; Trials B and $\mathrm{D}$ entailed $6 \mathrm{wk}$ at $10^{\circ} \mathrm{C}$ followed by $3 \mathrm{wk}$ at $20^{\circ} \mathrm{C}$

\begin{tabular}{|lccc|}
\hline Trial & Before & After & Binomial test \\
\hline Summer & & & \\
A (49 cols) & 0 & 12 & $\mathrm{p}<0.05$ \\
B (53 cols) & 0 & 11 & $\mathrm{p}<0.05$ \\
Autumn & & & \\
C (46 cols) & 4 & 11 & $\mathrm{p}=0.118$ \\
D (44 cols) & 4 & 16 & $\mathrm{p}<0.05$ \\
\hline
\end{tabular}


Table 4. Fredericella sultana infected with Tetracapsuloides bryosalmonae. Frequency and percentage of bryozoan colonies in which overt infections developed (+sacs) or did not develop (-sacs) after $6 \mathrm{wk}$ when exposed to $10^{\circ} \mathrm{C}$ for $3 \mathrm{wk}$ followed by exposure to $20^{\circ} \mathrm{C}$ for $3 \mathrm{wk}$ (Trials $\mathrm{A}$ and $\mathrm{C}$ ) and when exposed to $10^{\circ} \mathrm{C}$ for entire $6 \mathrm{wk}$ period (Trials B and D) during summer and autumn 2004

\begin{tabular}{|lcc|}
\hline \multirow{2}{*}{ Trial } & \multicolumn{2}{c|}{ Frequency $(\%)-$-sacs } \\
\cline { 2 - 3 } & + sacs & \\
Summer & $49(57.0)$ & $37(43.0)$ \\
A & $57(50.0)$ & $57(50.0)$ \\
B & & \\
Autumn & $15(32.6)$ & $31(67.4)$ \\
C & $4(8.7)$ & $42(91.3)$ \\
D & & \\
\hline
\end{tabular}

sponses, characteristic in most systems (Thomas \& Blanford 2003), would be anticipated over a greater range of environmental temperatures and may underly our simple linear trajectories.

We found that increased temperatures and temperature fluctuation can provoke, accelerate and prolong the proliferation of infective stages of Tetracapsuloides bryosalmonae. Increasing temperatures were accompanied by greater proportions of colonies developing overt infections in Expt 1 (Figs. 1a \& 2) when colonies were maintained under different temperature regimes for $4 \mathrm{wk}$. The results of Expt 2 provide independent and strong confirmation of this interpretation. Significantly more cases of overt infections developed in colonies transferred to $20^{\circ} \mathrm{C}$ for $3 \mathrm{wk}$ than in colonies that remained at $10^{\circ} \mathrm{C}$. Furthermore, the proliferation

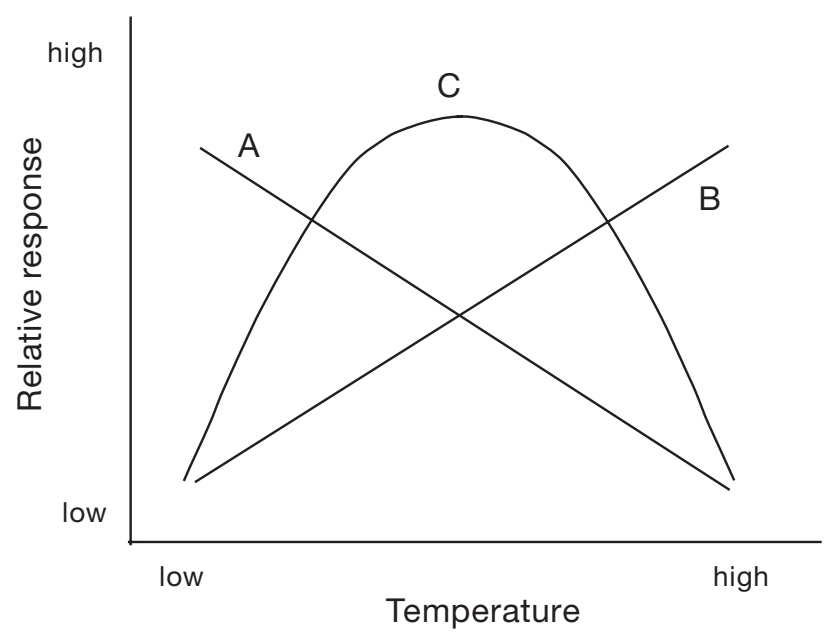

Fig. 2. Tetracapsuloides bryosalmonae responses to temperature. A: prevalence of covert infection and of latency period; B: prevalence of overt infection; C: duration of overt infections. Relative relationships and exact shapes of response trajectories are not clear and probably vary with season of parasitic sacs in the latter group when placed subsequently at $20^{\circ} \mathrm{C}$ indicated that infections were indeed present and therefore that low temperatures had inhibited the development of overt infections. Note that the overall consistency of our results and the replication over time (summer, autumn, winter: Expt 1; summer, autumn: Expt 2) indicate that confounding effects arising from pseudoreplication (a result of space constraints, see 'Materials and methods') can be disregarded.

Increasing temperatures were associated with lower proportions of colonies in which infections remained covert, a result which further supports the influence of temperature on parasite proliferation. The exception was in summer when similar low proportions of covert infections prevailed regardless of temperature regime. The latter result suggests that a low, residual proportion of covert infections in bryozoan populations may be maintained at all times. This is further supported by the low proportion of covert infections that was always maintained at $20^{\circ} \mathrm{C}$ regardless of season. Our demonstration of persistent covert infections adds to the growing appreciation, as a result of molecular evidence, that covert infection strategies may be widespread and play an important role in selection for virulence (e.g. Burden et al. 2003).

The period of time for infections to develop (latency) decreased with increasing temperature (Figs. 1c \& 2). Temperature also had an effect on duration of overt infection, which was longest at $14^{\circ} \mathrm{C}$ and shortest at $20^{\circ} \mathrm{C}$. However, a notable outcome was that the time of trials was also influential. For instance, the degree to which temperature influenced the development of overt infection varied between seasons, and at $20^{\circ} \mathrm{C}$ both latency and duration of infection were greatest in summer. Such context-dependency with regard to thermal regimes demonstrates the danger of adopting values for general predictive purposes based on evidence obtained from single time points and implies that temperature could have profound implications for host-parasite dynamics and evolution (e.g. Thomas \& Blanford 2003, Mitchell et al. 2005).

Despite the variation imposed by season on parasite proliferation, our results nevertheless are consistent and imply that moderate increases in temperature and prolonged periods of warmer temperatures can be expected to promote the development of overt infections in the bryozoan population from which our material was collected. The temperatures of the River Cerne recorded at the time of sampling for this study (Table 2) along with those recorded at other times (range $=6$ to $15^{\circ} \mathrm{C}$; Tops 2004 and unpubl. data) were always below our highest experimental temperature of $20^{\circ} \mathrm{C}$ and often below the intermediate experimental temperature of $14^{\circ} \mathrm{C}$. The overall responses of Tetracapsuloides 
bryosalmonae to elevated temperatures shown here imply that elevated temperatures will provoke higher levels of overt infection in other infected bryozoan populations. Indeed, temperature is widely regarded as the most important abiotic factor to affect parasite life cycles, with elevated temperatures generally leading to increased growth, development and maturation (see Marcogliese 2001 for review).

An important question, given the influence of temperature on parasite proliferation, is whether the bryozoan hosts can sustain such infection. If bryozoans die or undergo reduced growth from temperature-driven overt infection (i.e. from increased virulence) or from elevated temperatures themselves, then the threat posed by PKD to wild and farmed salmonids could diminish or vanish. Such scenarios are highly unlikely. As a group, freshwater bryozoans flourish at 15 to $28^{\circ} \mathrm{C}$ (Wood 2001), and since Tetracapsuloides bryosalmonae has a broad bryozoan host range (infecting putatively primitive to derived species, Okamura et al. 2001), increasing temperatures would not be expected to drive extinction of hosts and parasites. Furthermore, we found that the majority of Fredericella sultana colonies survived at $20^{\circ} \mathrm{C}$ and that both overt and covert infections imposed minimal costs to bryozoan hosts. Indeed, infection either had no influence on or actually increased bryozoan growth, while host survivorship was only reduced at the highest temperature in the case of overt infection (data to be presented in separate publication).

It is unclear to what extent these results arise from direct responses of Tetracapsuloides bryosalmonae to temperature vs. temperature-dependency in host defence. However, evidence that $T$. bryosalmonae undergoes temperature-driven proliferation in fish hosts (Gay et al. 2001) indicates that the parasite is capable of responding directly to temperature. Lack of proliferation in fish hosts at low temperatures cannot be explained by host defence, since fish immune responses are suppressed at low temperatures. A general temperature-driven acceleration of the parasite life cycle (Chubb 1979, Pojmanska et al. 1980) along with temperature-dependency in host manipulation or host response to parasitism (with a threshold between 14 and $20^{\circ} \mathrm{C}$ ) may jointly characterise this system.

\section{PKD, climate change and salmonid declines: a wake-up call}

Sustained periods of increased water temperatures can be anticipated in many present-day temperate and boreal environments, and elevated temperatures within the range of temperatures studied here will be common. For instance, from 1953 to 2000 the range in the mean summer water temperatures of the Fraser River in British Columbia was 15 to $19^{\circ} \mathrm{C}$. During this period, water temperatures increased by $0.022^{\circ} \mathrm{C} \mathrm{yr}^{-1}$, and modelling predicts that the mean summer water temperature will increase by $1.9^{\circ} \mathrm{C}$ during the period 2010 to 2099 (Morrison et al. 2002). While increased bryozoan host mortality at higher temperatures may partially offset parasite production, Tetracapsuloides bryosalmonae infective stages are nevertheless likely to be present in much greater numbers, as higher proportions of bryozoan colonies should be infected (Fig. 1a). Furthermore, the negligible mortality of infected bryozoans at $14^{\circ} \mathrm{C}$ (data not shown), the highest survivorship of uninfected bryozoans at $14^{\circ} \mathrm{C}$ (data not shown), and the increased prevalence of overt infections at $14^{\circ} \mathrm{C}$ (relative to those at $10^{\circ} \mathrm{C}$ ) all suggest that predicted increases for globally averaged air temperatures of at least $1.4^{\circ} \mathrm{C}$ by 2100 (Schneider 2001) will be accompanied by widespread enhancement of parasite levels, particularly as boreal freshwater systems warm up. Our results indicate that such increasing temperatures will drive the greater production of infective stages of $T$. bryosalmonae and suggest that a seasonal extension of elevated temperatures will be accompanied by both earlier and prolonged development and release of infective stages. PKD outbreaks should be further exacerbated by increased temperatures promoting parasite proliferation in fishes (Gay et al. 2001), prolonged stimulation of the fish immune response (thereby increasing disease severity; Naich et al. 2003), and infection challenges earlier in the life history. Indeed, PKD is already associated with increased mortality of brown trout in stretches of Swiss rivers that have undergone a significant increase in the maximum annual water temperature (Wahli et al. 2002, Borsuk et al. 2006). The absence of evidence for increasing levels and severity of PKD in other places is almost certainly due to lack of data.

Freshwater bryozoans as a group are generally widespread (Wood 2001), and recent surveys confirm that many species occur throughout Norway (Økland \& Økland 2001, Økland et al. 2003). In addition, records of PKD extend to Scandinavian regions (Hedrick et al. 1993). Thus, the predicted increases in prevalence and severity of PKD in more northerly regions should not depend on the introduction of Tetracapsuloides bryosalmonae. Nevertheless, colonisation of more northerly regions would also be anticipated by hosts and associated parasites as a result of temperature change. The accumulating evidence for the transport of viable bryozoan statoblasts by waterfowl (Freeland et al. 2000, Charalambidou et al. 2003, Figuerola et al. 2003), demonstrations of infection of statoblasts by malacosporean parasites of bryozoans (Taticchi et al. 2004, Hill \& Okamura unpubl. data) and the body of ev- 
idence for recent climate-driven range shifts in other organisms (Walther et al. 2002) indicate that such colonisation should be achieved rapidly.

The emergence of PKD in warmer rivers in conjunction with declining brown trout populations in Switzerland suggests that populations of salmonids generally not regarded as threatened or endangered are being seriously challenged by increasing temperatures, heavier parasite burdens and other associated changes. However, many salmonid populations are, in addition, threatened or endangered (Allendorf \& Waples 1996, Leidy \& Moyle 1998) as a result of recent and wide scale alterations to freshwater habitats including damming, irrigation projects, sedimentation caused by logging (Allendorf \& Waples 1996, Lichatowich 1999) and the introduction of nonindigenous species (Rahel 2000). The reduced levels of genetic diversity as a consequence of demographic bottlenecks (e.g. McCusker et al. 2000, Guinand et al. 2003) are likely to further intensify the challenge imposed by PKD and to generally compromise the ability of many populations to deal with the multiple stressors associated with climate change.

Temperature-driven PKD outbreaks can of course also be expected to have an increasing impact on the aquaculture industry. Indeed, farmed fishes are likely to be hit particularly hard by increasing global temperatures, as the industry is based on strains of fishes bred for specific traits such as increased growth rate and food conversion and delayed sexual maturation (Fjalestad et al. 2003). Such fishes are likely to be especially susceptible to parasitic diseases due to their relative genetic homogeneity along with the lack of antagonistic coevolution between hosts and parasites which characterises natural populations (Altizer et al. 2003) but is effectively absent in farmed populations as a result of continuous harvesting and variable stocking practices. Thus, although rainbow trout farming has contributed to the recent dominance of aquaculture in the animal food-producing sector in terms of growth (Tacon 2003), PKD can be expected to cause dwindling returns for many farms.

The general prognosis for salmonid populations is extremely worrying. Climate change has already been predicted to lead to local extirpations (reviewed by Marcogliese 2001) and, since all salmonids are susceptible to PKD, the effect of climate-driven parasite proliferation in both wild and farmed fishes is a major concern. At present there is no viable treatment apart from exposure of fry to infective stages of Tetracapsuloides bryosalmonae when temperatures are decreasing in autumn. For reasons unknown, such exposure results in the development of subclinical infections and effectively immunises fishes against developing fullblown PKD in the following year when temperatures rise (Longshaw et al. 2002). However, this procedure depends on the presence of infective stages when waters are cooling, restricts the production period, and is unachievable for wild fishes since susceptible young are generally produced when temperatures are rising. While global increases in temperature are a reality, elimination or reduction of thermal discharges to salmonid habitats could be a means of reducing future PKD-related wildfish mortalities in some situations.

\section{CONCLUSIONS}

Our results strongly indicate that PKD outbreaks will increase in both magnitude and severity in wild and farmed fishes as a result of climate-driven increases in global temperatures, which can be expected to enhance proliferation in invertebrate hosts. Despite regional heterogeneity, the predicted increase of globally averaged air temperatures (Schneider 2001), the lengthening of freeze-free periods in mid- and highlatitude regions, and the overall warming of the Earth's climate over the past $100 \mathrm{yr}$ (Walther et al. 2002) imply general changes in the phenology and geographical distribution of PKD as the organisms (parasites, bryozoans and fishes) respond to changing thermal regimes. Our results are a wake-up call and a warning to conservation biologists, recreational fisheries, and the aquaculture industry of an impending crisis for salmonids. Identification and early implementation of disease management strategies such as coordinated efforts to reduce thermal discharges might avoid or reduce crisis management at a later date.

Acknowledgements. We thank O. Robinson and D. Butterworth for their enthusiasm and support, M. Fellowes and $\mathrm{H}$. Hartikainen for help with data analysis, M. Fellowes and P. Hammond for comments on our manuscript, and Test Valley Trout, Trafalgar Fisheries and Defra (contract FC1112) for funding our work.

\section{LITERATURE CITED}

Allendorf FW, Waples, RS (1996) Conservation and genetics of salmonid fishes. In: Avise JC, Hamrick, JL (eds) Conservation genetics. Case histories from nature. Chapman \& Hall, New York, p 238-280

Altizer S, Harvell D, Friedle E (2003) Rapid evolutionary dynamics and disease threats to biodiversity. Trends Ecol Evol 18:589-596

Anderson CL, Canning EU, Okamura B (1999) Molecular data implicate bryozoans as hosts for PKX (phylum Myxozoa) and identify a clade of bryozoan parasites within the Myxozoa. Parasitology 119:555-561

Borsuk ME, Reichert P, Peter A, Schager E, Burckhardt-Holm $P$ (2006). Assessing the decline of brown trout (Salmo trutta) in Swiss rivers using a Bayesian probability network. Ecol Model 192:224-244

Burden JP, Nixon CP, Hodgkinson AE, Possee RD, Sait SM, 
King LA, Hails RS (2003) Covert infections as a mechanism for long-term persistence of baculoviruses. Ecol Lett 6: 524-531

Canning EU, Okamura B (2004) Biology and evolution of the Myxozoa. Adv Parasitol 56:43-131

Canning EU, Curry A, Feist SW, Longshaw M, Okamura B (1999) Tetracapsula bryosalmonae $\mathrm{n}$. sp. for PKX organism, the cause of PKD in salmonid fish. Bull Eur Assoc Fish Pathol 19:203-206

Canning EU, Tops S, Curry A, Wood TS, Okamura B (2002) Ecology, development and pathogenicity of Buddenbrockia plumatellae Schröder, 1910 (Myxozoa, Malacosporea) (syn. Tetracapsula bryozoides) and establishment of Tetracapsuloides $\mathrm{n}$. gen. for Tetracapsula bryosalmonae. J Eukaryot Microbiol 49:280-295

Charalambidou I, Santamaría L, Figuerola J (2003) Cristatella mucedo Cuvier 1798 (Bryozoa: Phylactolaemata) statoblasts survive duck gut passage. Arch Hydrobiol 157: $547-554$

Chubb JC (1979) Seasonal occurrences of helminths in freshwater fishes. Part II. Trematoda. Adv Parasitol 17:141-313

Daszak P, Cunninghan AA, Hyatt AD (2000) Emerging infectious diseases of wildlife-threats to biodiversity and human health. Science 287:443-449

de Kinkelin P, Gay M, Forman S (2002) The persistence of infectivity of Tetracapsula bryosalmonae-infected water for rainbow trout, Oncorhynchus mykiss (Walbaum). J Fish Dis 25:477-482

Feist SW, Longshaw M, Canning EU, Okamura B (2001) Induction of proliferative kidney disease (PKD) in rainbow trout Oncorhynchus mykiss via the bryozoan Fredericella sultana infected with Tetracapsula bryosalmonae. Dis Aquat Org 45:61-68

Feist SW, Peeler EJ, Gardiner R, Smith E, Longshaw M (2002) Proliferative kidney disease and renal myxosporidiosis in juvenile salmonids from rivers in England and Wales. J Fish Dis 25:451-458

Figuerola J, Green AJ, Santamaría L (2003) Passive internal transport of aquatic organisms by waterfowl in Donana, south-west Spain. Glob Ecol Biogeogr 12:427-436

Fjalestad KT, Moen T, Gomez-Raya L (2003) Prospects for genetic technology in salmonid breeding programmes. Aquac Res 34:397-406

Freeland JR, Noble LR, Okamura B (2000) Genetic consequences of the metapopulation biology of a facultatively sexual freshwater invertebrate. J Evol Biol 13:383-395

Gay M, Okamura B, de Kinkelin P (2001) Evidence that infectious stages of Tetracapsula bryosalmonae for rainbow trout Oncorhynchus mykiss are present throughout the year. Dis Aquat Org 46:31-40

Guinand B, Scribner KT, Page KS, Burnham-Curtis MK (2003) Genetic variation over space and time: analyses of extinct and remnant lake trout populations in the Upper Great Lakes. Proc R Soc Lond Ser B 270:425-433

Hedrick RP, MacConnell E, de Kinkelin P (1993) Proliferative kidney disease of salmonid fish. Annu Rev Fish Dis 3: 277-290

Henderson M, Okamura B (2004) The phylogeography of salmonid proliferative kidney disease in Europe and North America. Proc R Soc Ser Lond B 271:1729-1736

Kent ML, Andree KB, Bartholomew JL, El-Matbouli M, and 12 others (2001) Recent advances in our knowledge of the Myxozoa. J Eukaryot Microbiol 48:395-413

Lafferty KD, Porter JW, Ford SE (2004) Are diseases increasing in the ocean? Annu Rev Ecol Syst 35:31-54

Leidy RA, Moyle PB (1998) Conservation status of the world's fish fauna: an overview. In: Fiedler, PL, Kareiva PM (eds)
Conservation biology. 2nd edn, Chapman \& Hall, New York, p 187-227

Le Morvan C, Troutaud D, Deschaux P (1998) Differential effects of temperature on specific and nonspecific immune defences in fish. J Exp Biol 201:165-168

Lichatowich J (1999) Salmon without rivers. Island Press, Washington, DC

Longshaw M, Feist SW, Canning EU, Okamura B (1999) First identification of PKX in bryozoans from the United Kingdom-molecular evidence. Bull Eur Assoc Fish Pathol 19: 146-149

Longshaw M, Le Deuff RM, Harris AF, Feist SW (2002) Development of proliferative kidney disease in rainbow trout Oncorhynchus mykiss (Walbaum), following short-term exposure to Tetracapsula bryosalmonae infected bryozoans. J Fish Dis 25:443-449

Marcogliese DJ (2001) Implications of climate change for parasitism of animals in the aquatic environment. Can J Zool 79: 1331-1352

McCusker MR, Parkinson E, Taylor EB (2000) Mitochondrial variation in rainbow trout (Oncorhynchus mykiss) across its native range: testing biogeographical hypotheses and their relevance to conservation. Mol Ecol 9:2089-2108

Mitchell SE, Rogers ES, Little TJ, Read AF (2005) Host-parasite and genotype-by-environment interactions: temperature modifies potential for selection by a sterilizing pathogen. Evolution 59:70-80

Morrison J, Quick MC, Foreman MGG (2002) Climate change in the Fraser River watershed: flow and temperature projections. J Hydrol 263:230-244

Naich M, Bilqees FM, Khatoon N (2003) Proliferative kidney disease at Romsey fish farm on the River Test, Hampshire, UK. Pak J Biol Sci 6:1907-1909

Okamura B, Wood TS (2002) Bryozoans as hosts for Tetracapsula bryosalmonae, the PKX organism. J Fish Dis 25: 469-475

Okamura B, Anderson CL, Longshaw M, Feist SW, Canning EU (2001) Patterns of occurrence and 18S rDNA sequence variation of PKX (Tetracapsula bryosalmonae), the causative agent of salmonid proliferative kidney disease. J Parasitol 87:379-385

Økland KA, Økland J (2001) Freshwater bryozoans (Bryozoa) of Norway II: distribution and ecology of two species of Fredericella. Hydrobiologia 459:103-123

Økland KA, Økland J, Geimer G, Massard JA (2003) Freshwater bryozoans (Bryozoa) of Norway IV: Distribution and ecology of four species of Plumatella with notes on Hyalinella punctata. Hydrobiologia 501:179-198

Pojmanska T, Grabda-Kazubska B, Kazubski SL, Machalska J, Niewiadomska K (1980) Parasite fauna of five fish species from the Konin lakes complex, artifically heated with thermal effluents, and from Goplo Lake. Acta Parasitol 27: 319-357

Rahel FJ (2000) Homogenization of fish faunas across the United States. Science 288:854-856

Schneider SH (2001) What is 'dangerous' climate change? Nature 411:17-19

Siegel S, Castellan NJ Jr (1988) Nonparametric statistics for the behavioral sciences, 2nd edn. McGraw-Hill, New York

Subasinghe RP, Bondad-Reantaso MG, McGladdery SE (2001) Aquaculture development, health and wealth. In: Subasinghe RP, Bueno PB, Phillips MJ, Hough C, McGladdery SE, Arthur JR (eds) Aquaculture in the third millenium. Technical Proceedings of the Conference on Aquaculture in the Third Millenium. Food \& Agriculture Organization of the United Nations, Rome, p 167-191 
Tacon AJ (2003) Aquaculture production trends analysis. FAO Fish Circ 886:5-29

Taticchi MI, Gustinelli A, Fioravanti ML, Caffara M, Pieroni G, Prearo M (2004) Is the worm-like organism found in the statoblasts of Plumatella fungosa (Bryozoa, Phylactolaemata) the vermiform phase of Tetracapsuloides bryosalmonae (Myxozoa, Malacosporea)? Ital J Zool 71:143-146

Thomas MB, Blanford S (2003) Thermal biology in insectparasite interactions. Trends Ecol Evol 18:344-350

Tops S (2004) Ecology, life history and diversity of malacosporeans. Ph.D dissertation, University of Reading, Reading

Tops S, Okamura B (2003) Infection of bryozoans by Tetracapsuloides bryosalmonae at sites endemic for salmonid proliferative kidney disease. Dis Aquat Org 57:221-226

Tops S, Baxa DV, McDowell TS, Hedrick RP, Okamura B

Editorial responsibility: Wolfgang Körting,

Hannover, Germany
(2004) Evaluation of malacosporean life cycles through transmission studies. Dis Aquat Org 60:109-121

Wahli T, Knuesel R, Bernet D, Segner H, Pugovkin D, Burkhardt-Holm P, Escher M, Schmidt-Posthaus H (2002) Proliferative kidney disease in Switzerland: current state of knowledge. J Fish Dis 25:491-500

Walther GR, Post E, Convey P, Menzel A and 5 others (2002) Ecological responses to recent climate change. Nature 416: 389-395

Wood TS (2001) Bryozoans. In: Thorp J, Covich A (eds) Ecology and classification of North American freshwater invertebrates. Academic Press, San Diego, CA, p 505-525

Wood TS, Okamura B (2005) A new key to the freshwater bryozoans of Britain, Ireland and continental Europe, with notes on their ecology. Freshw Biol Assoc Sci Publ 63:1-113

Submitted: October 15, 2005; Accepted: January 30, 2006 Proofs received from author(s): June 9, 2006 